\title{
New vessel formation in retinal branch vein occlusion
}

\author{
JOHN S. SHILLING AND EVA M. KOHNER \\ From the Retinal Diagnostic Unit, Moorfields Eye Hospital, London
}

Neovascularization after retinal branch vein occlusion (RBVO) has long been recognized (Foster Moore, 1924; Jensen, 1936) and it has been noted more recently in a number of publications. Krill, Archer, and Newell (197I) found that three out of I4 patients had new vessel formation after RBVO; Michels and Gass (1974) found seven cases of retinal new vessels in 28 eyes and disc new vessels in two out of seven eyes.

We studied a series of patients with retinal branch vein occlusion. Our aim was to identify features in the clinical appearance and on fluorescein angiography that would indicate whether a patient with branch vein occlusion would develop new vessels and vitreous haemorrhage.

\section{Patients and methods}

\section{PATIENTS}

All patients with RBVO referred to the Retinal Diagnostic Department of Moorfields Eye Hospital during the last four years were assessed. Patients were included in the study if they presented within three months of their first visual symptom and had been followed-up for at least two years. Of the 87 eligible patients 19 were unable to attend the follow-up examination (two because they had died, the remaining I7 because they could not be traced or could not attend). This study therefore comprises 67 patients, who had 68 eyes affected by vein occlusion.

\section{METHODS}

All patients had ophthalmic and medical examinations. The eye assessment included a history of visual symptoms specifically related to vitreous haemorrhage; corrected visual acuity, direct and indirect ophthalmoscopy, and slit-lamp biomicroscopy. Colour photographs and fluorescein angiograms were performed at varying intervals, but each patient had at least three angiograms in the follow-up period of two years.

Colour photographs and fluorescein angiograms were examined for the site of vein occlusion, the presence of capillary dilatation (Fig. $1 a$ ), areas of capillary nonperfusion (Fig. 2), and the presence of neovascularization. The criterion for capillary non-perfusion was that an area of more than four disc diameters in size must be lacking

Address for reprints: J. S. Shilling, FRCS, Eye Department, St Thomas's Hospital, London SEI 7EH capillaries on fluorescein angiograms. Cotton-wool spots are usually of a smaller diameter, although they are always associated with capillary non-perfusion. Areas covered by haemorrhage were not included, since haemoglobin absorbs fluorescence and could therefore give a false impression of capillary closure (Figs $1 b, c$ ).

Most patients with pronounced non-perfusion of capillaries (Fig. 2) had areas that were much larger than four disc diameters in size devoid of capillaries and in many these extended into the retinal periphery of which no photographs were available.

The following criteria were used to diagnose the new vessels:

1. The presence of abnormal vessels flat or in front of the retina or optic disc as seen by slit-lamp biomicroscopy, binocular indirect ophthalmoscopy, or stereoscopic photography (Figs $3 a, b$ ).

2. The fluorescein angiographic change of progressive leakage of dye from these vessels (Figs $3 c, d$ ).

Medical examinations were carried out on 50 patients within three months of their first visit to Moorfields Eye Hospital. The other 18 were examined at various times up to two years.

The examination was directed mainly towards the cardiovascular system. Investigations included: haemoglobin, packed cell volume, erythrocyte sedimentation

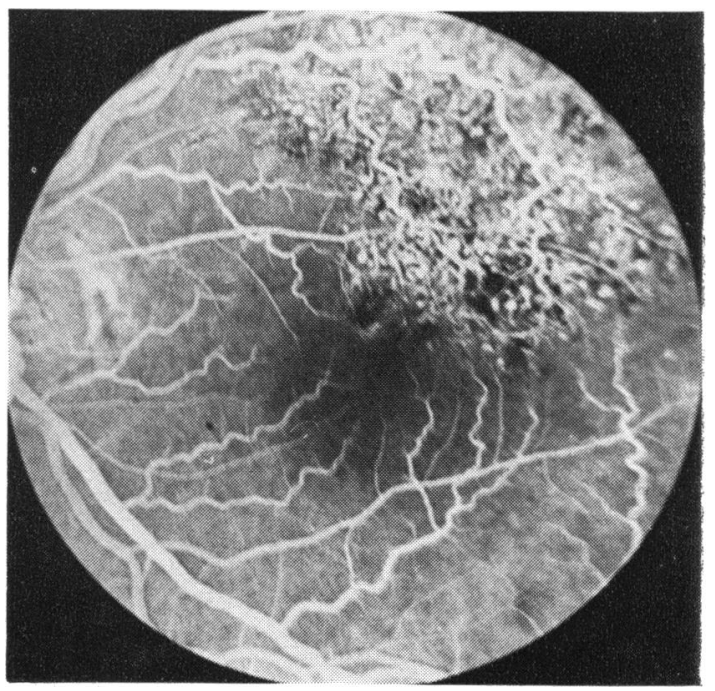

FIG. I(a) Fluorescein angiogram after absorption of haemorrhage, showing capillary dilatation 
rate, glucose tolerance test (in those under $6_{5}$ years old), fasting serum cholesterol and triglycerides, plasma urea and uric acid estimation; measurement of serum proteins and electrophoresis. Serum electrolytes were estimated in hypertensive patients. All patients had an electrocardiogram and chest $x$-ray.

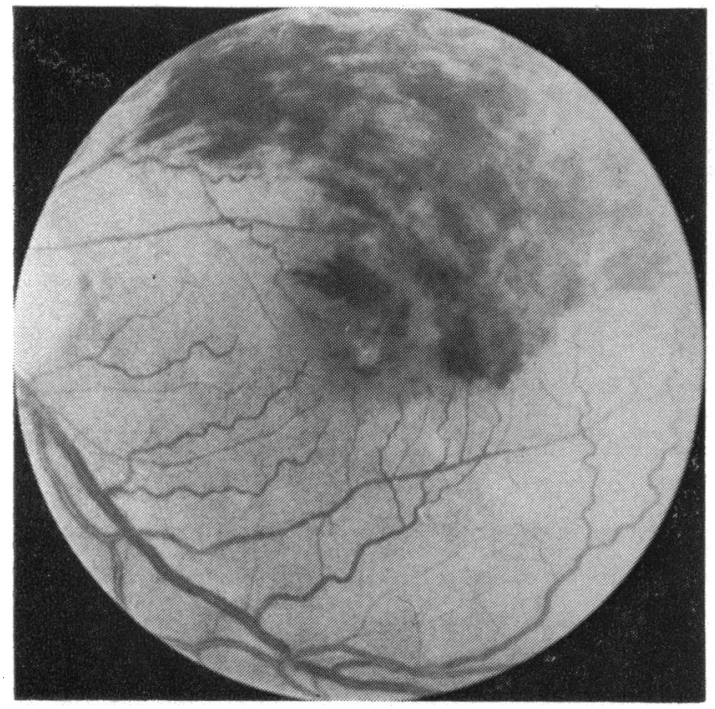

FIG. I(b) Same patient as Figs Ia, c from a colour photograph of a supero-temporal RBVO with retinal haemorrhages

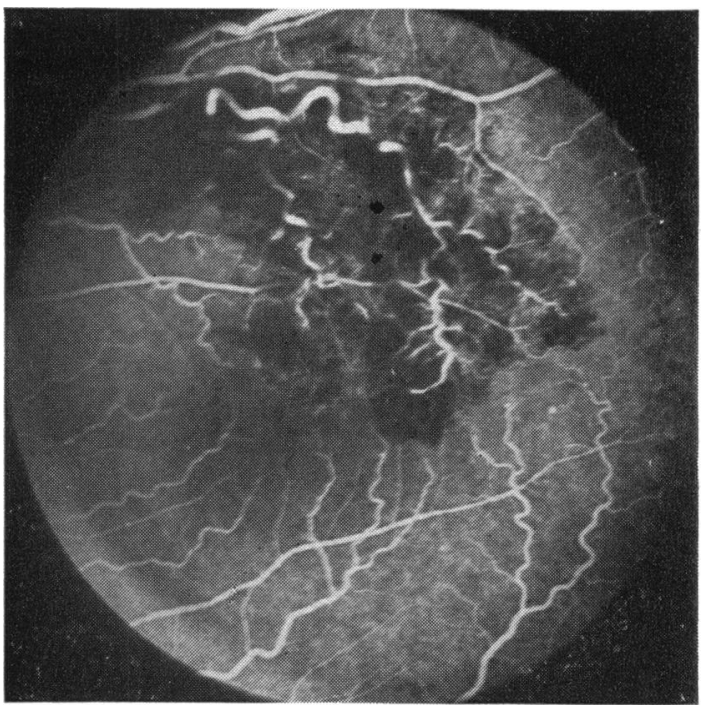

FIG. I(c) Fluorescein angiogram of same patient as

Fig. Ia showing apparent cxpillary non-perfusion

\section{ANALYSIS}

Patients were subdivided into four groups according to the site of occlusion:

1. Hemisphere vein occlusion

2. Main supero or infero-temporal vein occlusion

3. Macular vein occlusion
FIG. 2 Fluorescein angiogram of a supero-temporal venous occlusion showing large areas of capillary non-perfusion

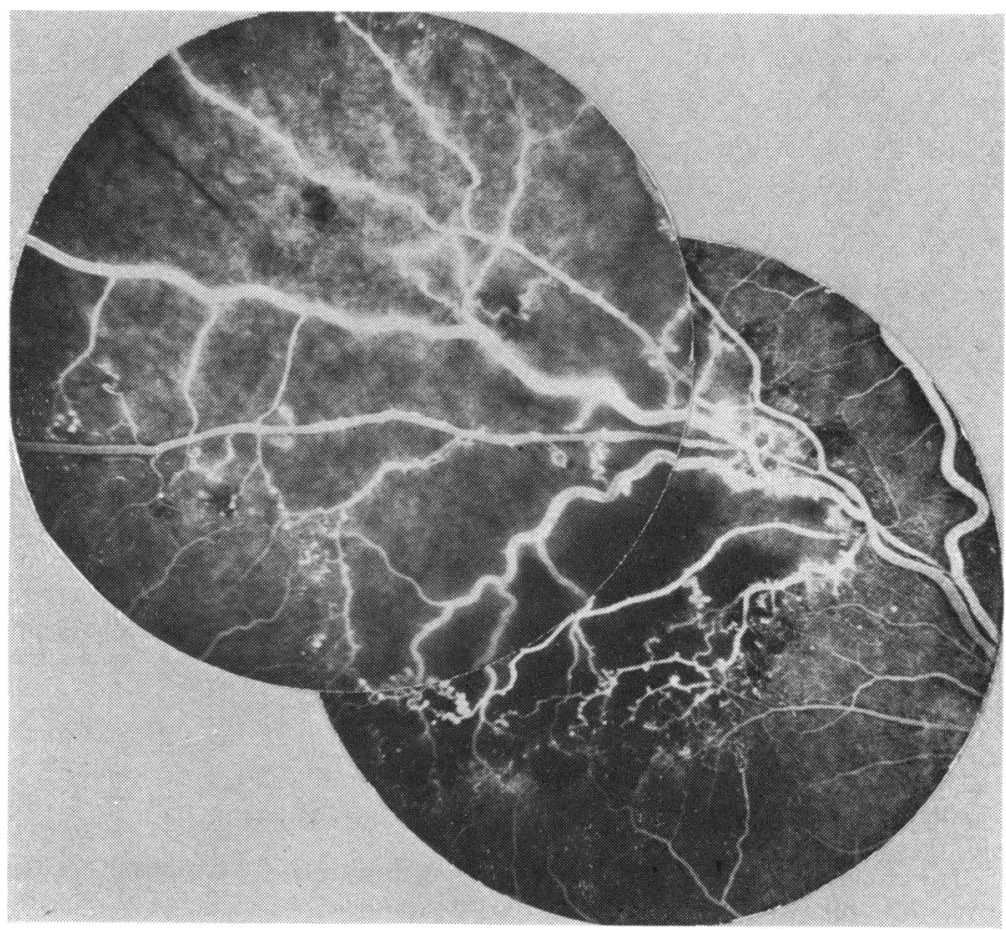


(3a)

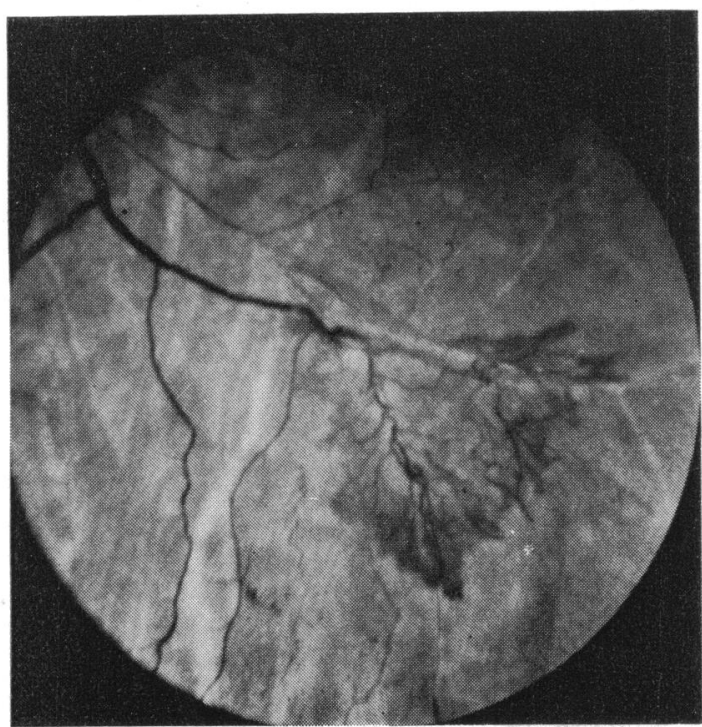

$(3 b)$

FIG. 3(a), (b) From a colour photograph of RBVO showing (a) disc, and (b) peripheral preretinal new vessels

4. Peripheral vein occlusion.

No patient in the study was placed in group 4 as none had had visual symptoms within three months of occlusion because by definition the macula was not involved.

Patients were also subdivided according to which of the following was their most predominant feature: capillary closure, dilatation, or the presence or absence of new vessels.

The groups were compared statistically using Student's $t$ test for unpaired samples when comparing numerical

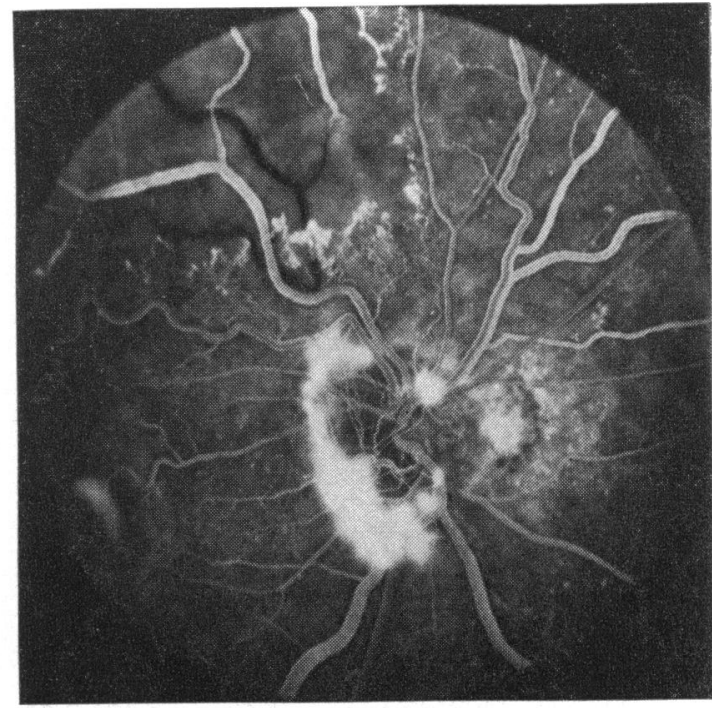

$(3 c)$

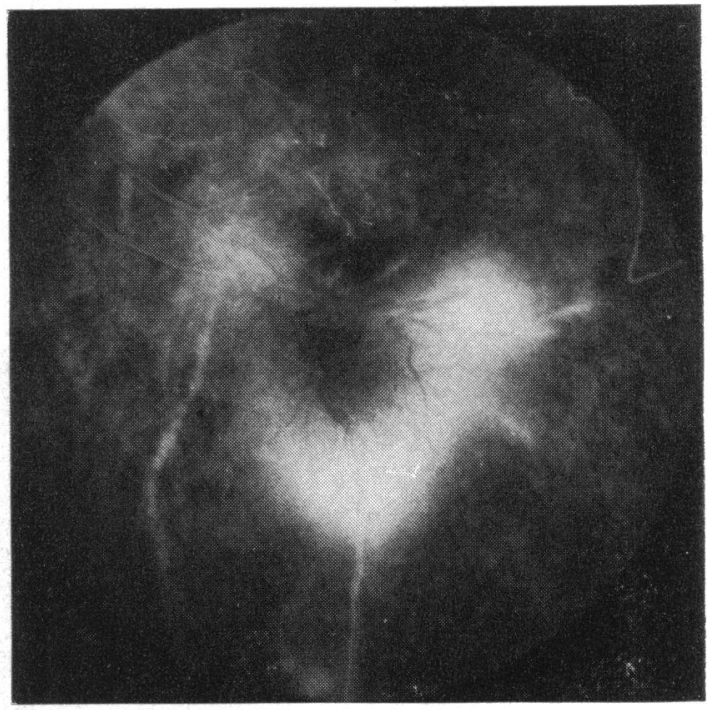

$(3 d)$

FIG. 3 (c), (d) Fluorescein angiogram of 3 (a) and 3 (b) showing leakage of dye from the new vessels

results (for example, blood pressure, plasma urea) and $\chi^{2}$ test when comparing presence or absence of features in the various groups.

\section{Results}

There were eight patients with hemisphere occlusion, 37 with main supero-temporal or inferotemporal occlusion and 23 with macular occlusion. Table I shows that of the 68 eyes affected by 
RBVO, there were 34 with pronounced capillary closure and 34 with capillary dilatation. While none of the eyes with predominant dilatation had new vessels, $2 \mathrm{I}$ of those with capillary closure had developed these lesions. The difference is highly significant $(\mathrm{P}<0.000 \mathrm{I})$.

Table II relates the site of occlusion with new vessel formation, capillary closure, and dilatation. No patient with macular RBVO had large areas of non-perfusion or new vessels, and only five of those with large branch vein occlusions had predominant dilatation. It is of interest that none of the patients with hemisphere occlusion developed new vessels.

Table III shows that in most patients new vessels occurred in the retinal periphery and there were only two patients who developed disc neovascularization without peripheral new vessels. Two-thirds of the patients with new vessels had at least one vitreous haemorrhage during the period of study (Table III), but no patient in this group suffered permanent loss of vision.

The early development of new vessels was a particularly interesting feature of this study.

A common finding seen on serial fluorescein angiograms was the ingrowth of blood vessels into the areas of non-capillary perfusion (Fig. 4). These vessels appeared to start as buds from the remaining

Table I Results in 68 eyes

\begin{tabular}{|c|c|c|c|}
\hline \multirow[b]{2}{*}{ Predominant feature } & \multirow[b]{2}{*}{ No. of eyes } & \multicolumn{2}{|c|}{ New vessels } \\
\hline & & No. & Per cent \\
\hline $\begin{array}{l}\text { Capillary dilatation } \\
\text { Capillary closure }\end{array}$ & $\begin{array}{l}34 \\
34\end{array}$ & $\begin{array}{r}0 \\
2 \mathrm{I}\end{array}$ & $\begin{array}{r}0 \\
62\end{array}$ \\
\hline
\end{tabular}

Table II Site of occlusion

\begin{tabular}{|c|c|c|c|c|}
\hline & \multirow[b]{2}{*}{ No. of eyes } & \multicolumn{3}{|c|}{ Site of occlusion } \\
\hline & & $\mathbf{I}$ & 2 & 3 \\
\hline $\begin{array}{l}\text { Closure and new vessels } \\
\text { Closure without new }\end{array}$ & 21 & - & 21 & - \\
\hline vessels & 13 & 2 & I I & - \\
\hline Dilatation & 34 & 6 & 5 & 23 \\
\hline
\end{tabular}

Table III Site of new vessels and incidence of vitreous haemorrhage

\begin{tabular}{lrrr} 
Site of new vessels & & No. of patients & $\begin{array}{l}\text { Vitreous } \\
\text { haemorrhage }\end{array}$ \\
\cline { 4 - 5 } \cline { 4 - 5 } Disc only & 2 & 2 \\
Periphery only & 15 & 10 \\
Disc and periphery & 4 & 2 \\
\hline
\end{tabular}

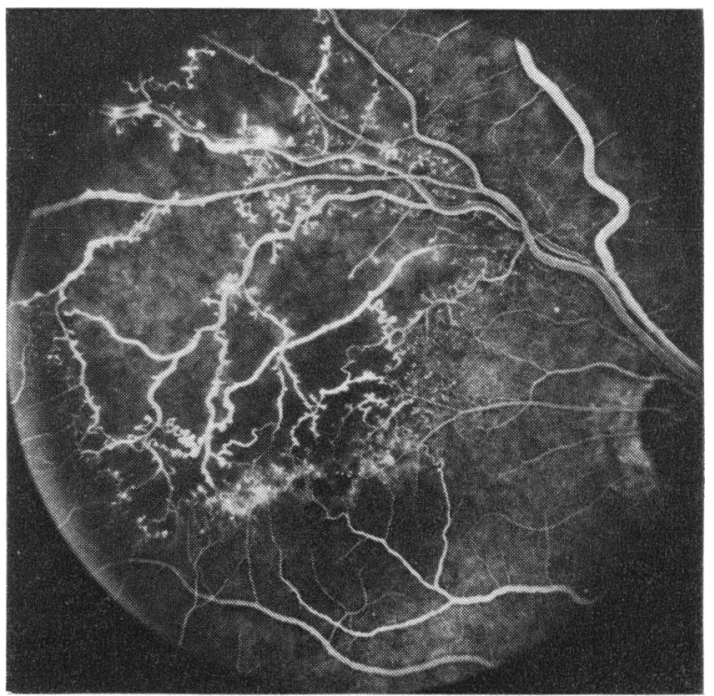

FIG. 4 Fluorescein angiogram of the same patient as Fig. 2 seven months later showing revascularization of the non-perfused areas

vessels and to grow at right-angles to these vessels, later to branch and revascularize the retina. The growing tips of these vessels appeared dilated and leaked small amounts of fluorescein. Their distribution was dissimilar from the normal retinal vasculature indicating that the vessels were newly formed. These intraretinal vessels, however, failed to leak fluorescein extensively in contrast with the new vessels which lay in front of the internal limiting membrane of the retina.

Table IV summarizes the medical findings. Patients with closure and new vessels (Group I), closure and no new vessels (Group 2), and dilatation (Group 3) were compared. The results were similar in most features relating to general health, but when those without new vessels (Groups 2 and 3 together) were compared with those who had new vessels, the plasma urea and plasma uric acid levels were significantly higher in the latter group $(\mathrm{P}<0.05)$.

Thirty-one of the 67 patients had diastolic blood pressure above $110 \mathrm{mmHg}$ and a further nine were being treated for high blood pressure at the time of their examination although not at the time of the diagnosis of the vein occlusion. In a further eight patients there was electrocardiographic evidence of old infarction or atrial fibrillation, possibly accounting for normal blood pressure.

In only nine patients out of the 68 examined was there no evidence of arterial disease; the results of their cardiovascular examinations, electrocardiograms, and serum lipids were normal and they had no sign of diabetes. Seven of these had pronounced capillary dilatation. 


\begin{tabular}{|c|c|c|c|c|c|c|c|c|}
\hline \multirow[b]{2}{*}{ Group (+ no.) } & \multirow[b]{2}{*}{$\begin{array}{l}\text { Age (years) } \\
\text { Mean (range) }\end{array}$} & \multicolumn{2}{|l|}{ Blood pressure } & \multirow[b]{2}{*}{$\begin{array}{l}\text { Plasma } \\
\text { urea } \\
(m g / 100 m l) \\
\text { Mean } \pm S E\end{array}$} & \multirow[b]{2}{*}{$\begin{array}{l}\text { Plasma } \\
\text { uric acid } \\
(m g / 100 m l) \\
\text { Mean } \pm S E\end{array}$} & \multirow[b]{2}{*}{$\begin{array}{l}\text { Serum } \\
\text { cholesterol } \\
(m g / 100 m l) \\
\text { Mean } \pm S E\end{array}$} & \multirow[b]{2}{*}{$\begin{array}{l}\text { Serum } \\
\text { triglyceride } \\
(m g / 100 m l) \\
\text { Mean } \pm S E\end{array}$} & \multirow[b]{2}{*}{$\begin{array}{l}\text { Haemoglobin } \\
(\mathrm{g} / \mathrm{I} 00 \mathrm{ml}) \\
\text { Mean } \pm S E\end{array}$} \\
\hline & & $\begin{array}{l}\text { Systolic } \\
(m m H g) \\
\text { Mean } \pm S E\end{array}$ & $\begin{array}{l}\text { Diastolic } \\
\text { (mmHg) } \\
\text { Mean } \pm S E\end{array}$ & & & & & \\
\hline $\begin{array}{l}\text { 1. Closure and new } \\
\text { vessels (2I) } \\
\text { 2. Closure without new }\end{array}$ & $59 \cdot 95(41-78)$ & $180.2 \pm 5.7$ & $105 \cdot 9 \pm 2 \cdot 6$ & $\begin{array}{l}* \\
39 \cdot 4 \pm 1 \cdot 9\end{array}$ & $6.59 \pm 0.33$ & $220 \cdot 1 \pm 7 \cdot 7$ & $119.2 \pm 14.9$ & $14.4 \pm 0.2$ \\
\hline $\begin{array}{l}\text { vessels (13) } \\
\text { 3. Dilatation ( } 34) \\
\text { 4. (2 and } 3 \text { combined) }\end{array}$ & $\begin{array}{l}61 \cdot 14 \quad(48-79) \\
59 \cdot 83(27-72)\end{array}$ & $\begin{array}{l}173 \cdot 6 \pm 7 \cdot 5 \\
173 \cdot 3 \pm 4 \cdot 1\end{array}$ & $\begin{array}{l}100 \cdot 0 \pm 5 \cdot 7 \\
102 \cdot 3 \pm 2 \cdot 3\end{array}$ & $\begin{array}{l}36 \cdot 7 \pm 2 \cdot 0 \\
34 \cdot 23 \pm 1 \cdot 5\end{array}$ & $\begin{array}{l}6.14 \pm 0.37 \\
5.00 \pm 0.2\end{array}$ & $\begin{array}{l}240.4 \pm 10 \cdot 1 \\
232 \cdot 9 \pm 7 \cdot 1\end{array}$ & $\begin{array}{l}164.9 \pm 44.7 \\
117.9 \pm 8.8\end{array}$ & $\begin{array}{l}13.7 \pm 0.5 \\
17.0 \pm 0.3\end{array}$ \\
\hline No new vessels (47) & - & $173 \cdot 0 \pm 3 \cdot 6$ & $102 \cdot 1 \pm 2 \cdot 4$ & $34 \cdot 9 \pm 1 \cdot 3$ & $5 \cdot 61 \pm 0.3$ & $232 \cdot 8 \pm 5 \cdot 9$ & $130.7 \pm 13.8$ & $13.9 \pm 0.2$ \\
\hline
\end{tabular}

* Significantly different from Group 4 (P<0.05)

\section{Discussion}

Neovascularization is common in many of the vascular retinopathies-for example, diabetes mellitus (Kohner, I975), sickle cell disease (Goldberg, 197I), retinal periphlebitis (Eales, 1880; Asdourian, Goldberg, and Busse, 1975; Sanders and Shilling, 1976) and in various haematological disorders (Ring, Pearson, Sanders, and WetherleyMein, 1976).

The frequent occurrence of neovascularization after retinal branch vein occlusion is shown in this paper. Although its cause is as yet unknown there is evidence that 'hypoxic' retina in some way stimulates it (Wise, 196I ; Ashton, 196I). Areas of capillary non-perfusion in the retina are ischaemic and probably hypoxic. Our finding that neovascularization occurs only in the presence of capillary nonperfusion strongly supports the ischaemic theory of neovascularization. Indeed there is a better correlation between capillary non-perfusion and neovascularization in branch vein occlusion than in most other retinopathies. It is interesting that peripheral non-perfusion of the retina appears to be the relevant factor and that central capillary non-perfusion does not seem to have the same stimulating effect, probably because the areas are not sufficiently large and diffusion may overcome the ischaemia.

The early development of new vessels into areas of non-perfusion is of interest and is similar to that demonstrated after experimental branch vein occlusion in monkeys (Hamilton, Kohner, Rosen, and Bowbyes, 1974). As shown both in animals and man there is very little dye leakage from these intraretinal new vessels and vitreous haemorrhage does not occur from them. A significant number of patients with preretinal new vessels had vitreous haemorrhages and this is therefore a serious complication of retinal branch vein occlusion.

It is of interest that levels of plasma urea and uric acid were higher in those patients with vascular occlusion and new vessels than in those without. Renal failure is associated with thrombosis in various veins, and in a group of I I 2 patients with central retinal vein occlusion Kohner and Cappin (1974) found three with chronic renal failure. In a recent publication (Ring and others, 1976) it was noted that viscosity was higher in those patients with vein occlusion (both central and branch) who had pronounced capillary closure. The exact cause of thrombotic episodes in renal disease is not known, nor do we know why some patients have predominant capillary closure. These findings should stimulate further work in both the pathogenesis of retinal vein occlusion and the cause of thrombotic episodes in chronic renal disease.

The main aim of this study was to help to determine the prognosis for an individual patient with RBVO and indicate lines of possible treatment and prophylaxis. First, we have shown that neovascularization does not occur secondary to small macular retinal branch vein occlusions. Secondly, fluorescein angiography after a vein occlusion will assess the presence of peripheral capillary nonperfusion and the possibility of late neovascularization may be predicted. There are important therapeutic implications from our findings. Ablation of peripheral ischaemic retina by photocoagulation has been used to treat new vessels on the disc, particularly in diabetes (Diabetic Retinopathy Study Research Group, 1976) and this also appears to be a rational form of treatment in the neovascular complications of branch vein occlusion by which means the ischaemic stimulus to neovascularization may be reduced. Although preretinal new vessels may be destroyed directly by photocoagulation, this is difficult with disc neovascularization and it is in the treatment of this complication that photocoagulation of the ischaemic quadrant of the retina may be the most effective form of therapy. The high incidence of neovascularization raises the possibility of reducing the chances of this complication by early photocoagulation of non-perfused retina.

We thank Miss Rita Clarke for secretarial assistance and Mr Rolf Sennhenn for preparing the illustrations. 


\section{References}

ASDourian, G. K., Goldberg, M. F., and BUSSE, B. J. (1975) Arch. Ophthal., 93, 787

ASHTON, N. (I96I) Trans. ophthal. Soc. U.K., 81, I 45

DIABETIC RETINOPATHY STUDY RESEARCH GROUP (1976) Amer. F. Ophthal., 81, I

EALES, H. (1880) Bgham med. Rev., 9, 262

FOSTER MOORE, R. (1924) Brit f. Ophthal., Monograph Suppl. 2, I-12. Pulman, London

GOLDBERG, S. (1971) Arch. Ophthal., 85, 428

hamilton, A. M., Kohner, E. M., Rosen, D., and Bowbyes, J. A. (1974) Proc. roy. Soc. Med., 67, 1045

JENSEN, v. A. (1936) Acta ophthal. (Kbh.), suppl. Iо, I

KOHNER, E. M. (1975) Acta med. scand., suppl. 578, 4I

, and CappIN, J. M. (1974) Proc. roy. Soc. Med., 67, 1052

KRILl, A. E., ARCHER, D., and NEWEll, F. W. (I97I) Arch Ophthal., 85, 48

Michels, R. G., and Gass, J. D. M. (1974) Trans. Amer. Acad. Ophthal. Otolaryng., 78, 66

RING, C. P., PEARSON, T., SANDERS, M.D., and WeThERLEY-MeIN, G. (1976) Brit. F. Ophthal., 60, 397

SANDERS, M. D., and SHILling, J. S. (1976) Trans. ophthal. Soc. U.K., 96, 140

WISE, G. N. (1961) Amer. F. Ophthal., 52, 637 